\title{
Ring artefacts in cranial CT
}

\section{Akilesh Ramasamy, Balasubramanian Madhan, Balasubramanian Krishnan}

Department of Dentistry Jawaharlal Institute of

Postgraduate Medical Education and Research, Puducherry, India

Correspondence to Dr Akilesh Ramasamy, akident@gmail.com

Accepted 8 July 2018

\section{DESCRIPTION}

A ring or arc artefact in a CT is a hardware related artefact that occurs due to a defective or miscalibrated detector. It is more common

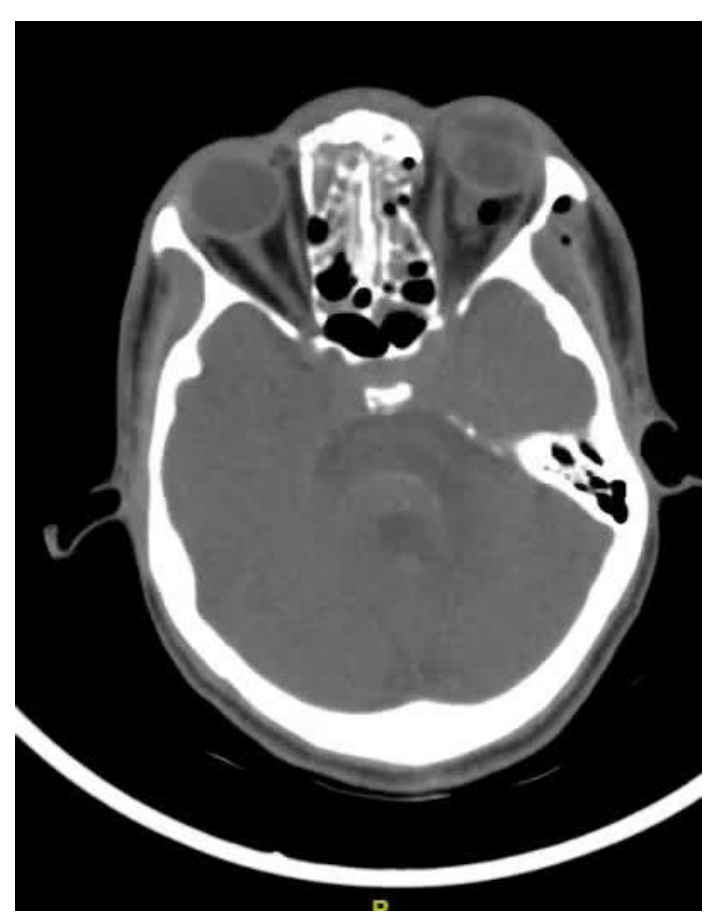

Video 1 Serial sections of the scan (soft-tissue window) showing ring artefact.

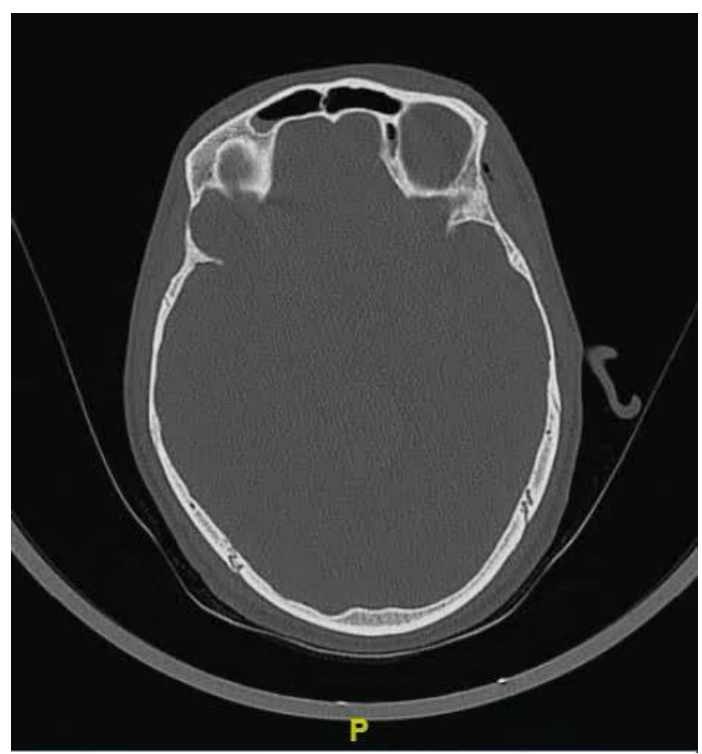

Video 2 Serial sections of the scan (bone window) showing ring artefact.

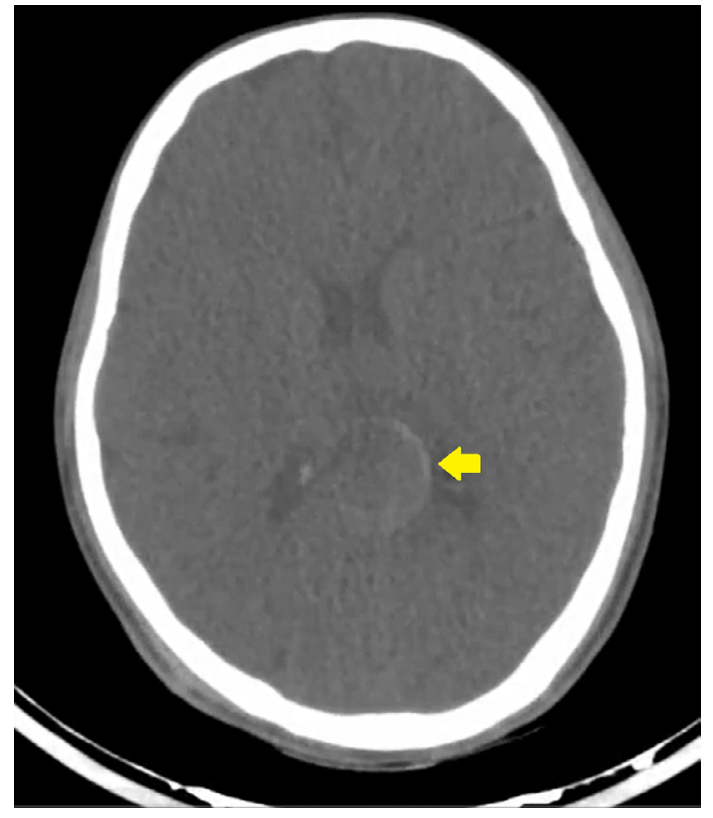

Figure 1 Axial section of scan showing the ring artefact (yellow arrow).

with third-generation CT scanners with solidstate detectors. It appears as complete circles (sequential scans), annular rings (multiple circles) or partial rings (helical/multislice CT) at the same spot near the isocentre in multiple sections. ${ }^{12}$ Recognising this artefact is important as it may be subtle and misinterpreted as a pathological entity by the novice clinician. ${ }^{3}$ This artefact is usually more clearly visualised in the soft-tissue window of CT scans (video 1 ) than in the bone window (video 2).

Presented here is a case where an arc artefact was noted in the CT made for the evaluation of facial fractures (figure 1, videos 1 and 2). The artefact posed no diagnostic challenge as it exhibited the characteristic features for easy identification and was away from the region of interest.

\section{Learning points}

- Ring artefacts in CT appear as complete circles, annular or partial rings in multiple slices.

- They occur due to a defective or miscalibrated detector in CT hardware.

- Key to identification is the occurrence of smooth circular artefacts near the isocentre in sequential scans.

Twitter@akident 
Contributors AR identified the important nature of the finding, wrote the draft of the article, collected materials, finalised and approved the final proof of the article. BM was involved in correcting the draft, suggesting edits and approving the final proof. BK was involved in correcting the draft, suggesting edits and approving the final proof.

Funding The authors have not declared a specific grant for this research from any funding agency in the public, commercial or not-for-profit sectors.

Competing interests None declared.

Patient consent Obtained.
Provenance and peer review Not commissioned; externally peer reviewed.

\section{REFERENCES}

1 Jha AK, Purandare NC, Shah S, et al. Identification of a unique cause of ring artifact seen in computed tomography trans-axial images. Indian J Nucl Med 2013:28:232-3.

2 Brahme A, Panetta D, Demi M. Comprehensive biomedical physics. 1st ed. Amsterdam: Elsevier, 2014.

3 Fosbinder R, Kelsey C. Essentials of radiologic science. New York: McGraw-Hill Medical Publishing Division, 2002.

Copyright 2018 BMJ Publishing Group. All rights reserved. For permission to reuse any of this content visit http://group.bmj.com/group/rights-licensing/permissions.

BMJ Case Report Fellows may re-use this article for personal use and teaching without any further permission.

Become a Fellow of BMJ Case Reports today and you can:

- Submit as many cases as you like

- Enjoy fast sympathetic peer review and rapid publication of accepted articles

- Access all the published articles

- Re-use any of the published material for personal use and teaching without further permission

For information on Institutional Fellowships contact consortiasales@bmjgroup.com

Visit casereports.bmj.com for more articles like this and to become a Fellow 